\title{
Distribution of Heavy Metals, Chemical Fractions and Ecological Risks around a Molybdenum Mine in Liaoning Province, China
}

\author{
Jiao $\mathbf{Q u}^{1,2 *}$, Xing Yuan ${ }^{1}$, Xinhong Wang ${ }^{1}$, Peng Shao' and Qiao Cong ${ }^{2}$
}

${ }^{1}$ School of Chemistry and Chemical Engineering, Bohai University, Jinzhou 121013, China

${ }^{2}$ School of Urban and Environmental Sciences, Northeast Normal University, Changchun 130024, China

\begin{abstract}
The total contents of lead, arsenic, mercury, chromium, cadmium, zinc, copper, molybdenum and nickel were determined in soils collected from mining and agricultural areas around the molybdenum mine in Liaoning Province, China. The distribution, chemical fractions and ecological risks of heavy metals in soils were investigated and assessed. It was found that: the degrees of warning for all soils, both mining industry areas and agricultural areas, were serious warning. The results meant that all soils were contaminated seriously by heavy metals. The observed scheme of chemical fractions for heavy metals in soils of different sites was as follows commonly: residual>oxidable> reducible>acid soluble. The sources of heavy metals in top soils around the mine were as follows: dust fall, residue in the open air, higher background in soil-forming process, accompaniment element, automobile exhaust, wear of tires and brakes, release of heavy metals from ore tailing, the application of pesticides and irrigation with wastewater.
\end{abstract}

Keywords: Heavy metal; Top soil; Fraction; Assessment; Mine

\section{Introduction}

Anthropogenic activities such as mining and smelting of metal ores have increased the prevalence and occurrence of heavy metal contamination at the Earth's surface. Soil and water resources have been contaminated with heavy metals by the process of mining and smelting activities throughout the world [1]. In the former, soils around ore can be polluted by metal mine mining due to mineral action in soil under the reaction with environmental factors like water, air and heat for a very long time; caused by leaching during piling of mining waste rock, and by leakage of mining wastewater containing high level of heavy metals [2]. In many ways, human health is closely related to the quality of soil and especially to its degree of pollution [3]. The heavy metals, which can be accumulated by organisms and enter into the food chain, are toxic to human and other living beings. In many instances, biological toxicity of the elements is related more closely to the concentrations of particular physicochemical forms [4]. Some governmental and regional institutions are devoting increased attention to soil pollution problems, and assessing the essential ecological functions and ecosystem services of soils in terrestrial environments [5].

Ecological risk warning assessment is derived from ecological risk assessment, which not only has the characteristics of quantitative analysis to some pollution evaluation methods, i.e. geo-accumulative index, synthetic index, but also can achieve the qualitative analysis through the correlation of quantitative evaluation value and alert degree connotation [6]. Ecological risk warning assessment is a generic term used to describe any formal process whereby ecological threats are identified, their likelihood of occurrence estimated or guessed, and their consequences articulated. Ecological risk warning assessment is a subset of environmental risk assessment. It focuses specifically on the elicitation, quantification, communication, and management of risks to the biotic environment. While environmental risk assessment dates back to the 1930s [7], Ecological risk warning assessment is relatively new and commenced as a United States Environmental Protection Agency (USEPA) project in the 1980s to develop tools for environmental regulation and management [8]. Since that time there have been rapid advances in the sophistication and complexity of Ecological risk warning assessment "tools" although, as noted by Kookana et al. [9], Ecological risk warning assessment currently suffers from a poor understanding of processes governing ecological risks and a paucity of appropriate data. Lots of studies on the pollution of soils around mine have been conducted recently, and these studies mainly focused on $\mathrm{Pb}, \mathrm{As}, \mathrm{Hg}, \mathrm{Cr}, \mathrm{Cd}, \mathrm{Zn}, \mathrm{Cu}$, and $\mathrm{Ni}$ in soils $[10,11]$. However, the high content of Mo in soil is harmful to plants [12,13]. The chlorisis, aetiolation, and blade deformity will occur when the content of Mo in plant is higher than $10 \mathrm{mg} \mathrm{kg}^{-1}$ [14]. And there are antagonism effects between $\mathrm{Mo}$ and $\mathrm{N}, \mathrm{S}, \mathrm{Cu}, \mathrm{Mn}, \mathrm{Fe}, \mathrm{Zn}$, which can influence human and other organisms on absorbing essential element [15-17]. In recent years, a great deal of effort has been devoted to study the contaminations of heavy metals (except for Mo) in soil around mine (except for Mo mine).

Inductively coupled plasma optical emission spectrometry (ICP$\mathrm{OES}$ ), is an analytical technique used for the detection of trace metals. It is a type of emission spectroscopy that uses the inductively coupled plasma to produce excited atoms and ions that emit electromagnetic radiation at wavelengths characteristic of a particular element [18-19]. ICP-OES is often used for analysis of trace elements in soil.

Nowadays, the determination of total concentrations of metals has been established cannot give sufficient information to assess the environment impact of substrates studied. The distribution of heavy metals in the various phases determines their behavior in the environment: mobility, bioavailability and toxicity. At present, the only laboratory routine available to determine metal binding forms is sequential extraction. It has been widely used for the fractionation of heavy metals in various substrates such as soils, sediments and sewage sludges. Among the fractionation methods available, Tessier and BCR are some of most cited $[20,21]$. However, the oxidisable step of the BCR protocol seemed more effective than that employed in Tessier's method [22]. In order to harmonize sequential extraction procedure, $\mathrm{BCR}$ protocol was recommended by Community Bureau of Reference

*Corresponding author: Jiao Qu, School of Chemistry and Chemical Engineering Bohai University, Jinzhou 121013, School of Urban and Environmental Sciences, Northeast Normal University, Changchun 130024, China, Tel: 086-416-3400302; Fax 086-416-3400302; E-mail: qujiao@bhu.edu.cn

Received March 21, 2012; Accepted April 25, 2012; Published May 04, 2012

Citation: Qu J, Yuan X, Wang X, Shao P, Cong Q (2012) Distribution of Heavy Metals, Chemical Fractions and Ecological Risks around a Molybdenum Mine in Liaoning Province, China. Vitam Trace Elem 1:104

Copyright: (c) $2012 \mathrm{Qu} \mathrm{J}$, et al. This is an open-access article distributed under the terms of the Creative Commons Attribution License, which permits unrestricted use, distribution, and reproduction in any medium, provided the original author and source are credited. 
(BCR, now superseded by the Standards, Measurement and Testing Programmer) [23]. Recently, because the significant inter laboratory variability was apparent, in particular in step 2 of the extraction, a thorough re-evaluation of this step of the protocol was conducted [24]. Later, some studies led to the development of a modified BCR sequential extraction procedure [25-27].

Herein, the objectives of this study were to report: (1) the distribution and chemical fractions of heavy metals in top soils of Mo mine; and (2) assessment to ecological risks of heavy metals in top soils of Mo mine.

\section{Material and Methods}

\section{Soil and underground water samplings}

The soils were the chernozems, collected $(0-20 \mathrm{~cm}$ deep) from mining industry areas (the collection site, 20 sampling points were selected randomly at a distance of $50 \mathrm{~m}$ to the plant; the transportation site, 20 sampling points were selected along and at a distance of $5 \mathrm{~m}$ to the road, the regular distance between each site is $100 \mathrm{~m}$; and tailing site, 20 sampling points were selected randomly at a distance of $50 \mathrm{~m}$ to the tailing pond) and agricultural areas (the vegetable field near the collection, transportation and tailing site, 20 sampling points were selected using a regular $100 \times 100 \mathrm{~m}$ grid laid over each agricultural area) near the Mo mine in Liaoning Province, China (N 40 $45^{\prime} 15^{\prime \prime}$, E $\left.120^{\circ} 51^{\prime} 45^{\prime \prime}\right)$. The morphotype of $\mathrm{Mo}$ is $\mathrm{MoS}_{2}$ in rock ore. The climate style belongs to the warm temperate zone, the annual average parameters were as follows: temperature $8.9^{\circ} \mathrm{C}$, rainfall $637.6 \mathrm{~mm}$. The soil sample was a composite sample of five sampling positions in one lattice, mixed homogeneously and sieved to $<2 \mathrm{~mm}$ after being air-dried [28]. The irrigation water used for agricultural areas was underground water. So, the underground water for irrigation was selected.

\section{Soil and underground water analyses}

All samples were analyzed for $\mathrm{pH}$, the contents of total mass and fractions for $\mathrm{Pb}, \mathrm{As}, \mathrm{Hg}, \mathrm{Cr}, \mathrm{Cd}, \mathrm{Zn}, \mathrm{Cu}, \mathrm{Mo}$, and Ni. Sequential extraction was performed using the modified three-stage procedure recommended by BCR (Table1). $1 \mathrm{~g}$ of soil sample in PTFE vessels (100 $\mathrm{mL}$ volume) with PTFE covers was treated as follows:

Step 1: A $40 \mathrm{~mL}$ volume of acetic acid $\left(0.11 \mathrm{~mol} \mathrm{l}^{-1}\right)$ was added to $1 \mathrm{~g}$ of soil in a PTFE vessel. The vessel was shaken for $16 \mathrm{~h}$ (over night) at room temperature in a mechanical shaker operating at 300 motions $\mathrm{min}^{-1}$ for $20 \mathrm{~min}$, the shaking speed was adapted in order to ensure a continuous suspension of the mixture. The extract was separated from the solid residue by centrifugation for $20 \mathrm{~min}$ and decanted into a polyethylene container and stored in a refrigerator at $4^{\circ} \mathrm{C}$ for analysis. The residue was washed with $20 \mathrm{~mL}$ of distilled water by shaking for 20 min, centrifuged and the washings discarded.

Step 2: To the residue from step 1, $40 \mathrm{~mL}$ of a freshly prepared hydroxylamine hydrochloride, $0.5 \mathrm{~mol} \mathrm{l}^{-1}(\mathrm{pH}$ was adjusted by adding of $25 \mathrm{~mL}$ of $2 \mathrm{~mol} \mathrm{l}^{-1} \mathrm{HNO}_{3}$ to 1 lit volumetric flask to the dissolved hydroxylamine hydrochloride $(34.75 \mathrm{~g})$ ) in deionized water. The extraction procedure was then performed as described above.

Step 3: A $10 \mathrm{~mL}$ of hydrogen peroxide $\left(8.8 \mathrm{~mol} \mathrm{l}^{-1}\right)$ was added carefully in small aliquots to the residue from step 2 . The vessel was loosely covered with the watch glass and digested at room temperature for $1 \mathrm{~h}$ with occasional manual shaking. Digestion was continued by heating the vessel to $85^{\circ} \mathrm{C}$ in a water bath for $1 \mathrm{~h}$, and then reduced the volume to less than $3 \mathrm{~mL}$ by further heating of the uncovered vessel. A second $10 \mathrm{~mL}$ of aliquot of hydrogen peroxide was added and the digestion procedure was repeated. Fifty milliliters of ammonium acetate $\left(1 \mathrm{~mol} \mathrm{l}^{-1}\right.$, adjusted to $\mathrm{pH} 2$ with nitric acid) were added to the cool moist residue. The sample was shaken, centrifuged and the extract was separated as described in step 1 .

$1 \mathrm{~g}$ of collected soils $(0-20 \mathrm{~cm})$ were weighed and placed in a Teflon plastic crucible. $5 \mathrm{~mL} \mathrm{HNO}_{3}, 10 \mathrm{~mL} \mathrm{HF}$ and $12 \mathrm{~mL} \mathrm{HClO}_{4}$ were added into soils and oscillated for $10 \mathrm{~h}$ under constant temperature $\left(80^{\circ} \mathrm{C}\right)$. When the samples were almost dried, $10 \mathrm{~mL}$ nitric acid (1:1) was added to dissolve the samples continually. $2 \mathrm{~mL}$ nitric acid (1:1) was added to $10 \mathrm{~mL}$ underground water. The dissolved soil samples and pre-treated underground water were transferred constantly to $50 \mathrm{~mL}$ volumetric flask to determine the total contents of toxic metals in soils [29]. The contents of total and fractions for $\mathrm{Pb}, \mathrm{As}, \mathrm{Hg}, \mathrm{Cr}, \mathrm{Cd}, \mathrm{Zn}, \mathrm{Cu}, \mathrm{Mo}$, and $\mathrm{Ni}$ in digestive solution and underground water were analyzed by the ICP-OES. The physical and chemical properties of the soils were: $\mathrm{pH}$ was 6.85 , content of organics matter was $17.94 \mathrm{~g} \mathrm{~kg}^{-1}$, cation exchange capacity was $7.06 \mathrm{c} \mathrm{mol} \mathrm{kg}^{-1}$, content of $\mathrm{CaCO}_{3}$ was $2.46 \mathrm{~g} \mathrm{~kg}^{-1}$, and the content of heavy metal in the soil was shown in Table 4 and 6 . The contents of $\mathrm{Pb}, \mathrm{As}, \mathrm{Hg}, \mathrm{Zn}, \mathrm{Cu}, \mathrm{Mo}$, and $\mathrm{Ni}$ in the underground water were $0.030,0.002,0.034,0.529,0.073,13.216,0.001 \mathrm{mg} \mathrm{l}^{-1}(\mathrm{Cd}$ and $\mathrm{Cr}$ were not detected), respectively.

\section{Ecological warning assessment}

The ecological risk warning assessment of soil heavy metal was the ecological risk index method $\left(\mathrm{I}_{\mathrm{FR}}\right)$ which was proposed by Rapant et al. [30]. Distinguish standards of ecological risk warning of soil are shown in Table 2 . The ecological risk warning assessment, which was established only for prostration and crisis caused by natural resources or the ecological risk, is narrow sense.

$$
\mathrm{I}_{\mathrm{ER}}=\operatorname{Sum}\left(\mathrm{C}_{\mathrm{Ai}} / \mathrm{C}_{\mathrm{Ri}}-1\right)
$$

$\mathrm{C}_{\mathrm{Ai}}$ is defined as the contents of actual measurement of the $\mathrm{i}$-th heavy metal, $\mathrm{mg} \mathrm{kg}^{-1} ; \mathrm{C}_{\mathrm{Ri}}$ is defined as the critical limit contents of the i-th heavy metal contamination. The limit value of evaluation standard of heavy metal pollution in soil (secondary standard) is used to assess in this paper (Table 3 ).

There was no quality standard of Mo in the environmental quality standard for contaminated soil of China (GB 15618-1995). So the pollution level of Mo in soil was not assessed in this study.

\begin{tabular}{|l|l|l|}
\hline extraction & reagent $(\mathrm{s})$ & nominal target phase $(\mathrm{s})$ \\
\hline acid soluble & $\mathrm{CH}_{3} \mathrm{COOH}\left(0.11 \mathrm{~mol} \mathrm{l}^{-1}\right)$ & $\begin{array}{l}\text { soil solutions, carbonates, } \\
\text { exchangeable metals }\end{array}$ \\
\hline reducible & $\mathrm{NH}_{2} \mathrm{OH} \cdot \mathrm{HCl}\left(0.5 \mathrm{~mol} \mathrm{l}^{-1}\right)$ & iron / manganese oxyhydroxides \\
\hline oxidable & $\left.\begin{array}{l}\mathrm{H}_{2} \mathrm{O}_{2}\left(8.8 \mathrm{~mol} \mathrm{l}^{-1}\right) \text { then } \\
\mathrm{CH}_{3} \mathrm{COONH}\end{array} \mathrm{mol} \mathrm{I}^{-1}\right), \mathrm{pH}=2$ & organic matter and sulfides \\
\hline residual & aqua regia & remaining, non-silicate bound metals \\
\hline
\end{tabular}

Table 1: Modified BCR three-step sequential extraction procedure.

\begin{tabular}{|c|l|l|}
\hline risk level & risk index & degree of warning \\
\hline 1 & $\mathrm{IER} \leq 0$ & no warning \\
\hline 2 & $0<\mathrm{IER} \leq 1.0$ & early warning \\
\hline 3 & $1.0<\mathrm{IER} \leq 3.0$ & light warning \\
\hline 4 & $3.0<\mathrm{IER} \leq 5.0$ & medium warning \\
\hline 5 & $\mathrm{IER}>5.0$ & serious warning \\
\hline
\end{tabular}

Table 2: Distinguish standard of ecological risk warning of soil.

\begin{tabular}{|l|l|l|l|l|l|l|l|l|}
\hline Element & As & $\mathrm{Cd}$ & $\mathrm{Cr}$ & $\mathrm{Cu}$ & $\mathrm{Hg}$ & $\mathrm{Ni}$ & $\mathrm{Pb}$ & $\mathrm{Zn}$ \\
\hline Content $\left(\mathrm{mg} \mathrm{kg}^{-1}\right)$ & 40 & 1.0 & 300 & 400 & 1.5 & 200 & 500 & 500 \\
\hline
\end{tabular}

Table 3: Evaluation standard of heavy metal pollution in soil (Grade III). 


\section{Statistical analysis}

All data obtained from this study were analyzed by SPSS 13.0. The differences among means were compared by least significant difference $(P<0.01)$. The soil samples were in triplicates for analysis.

\section{Results and Discussion}

\section{Heavy metal distribution and contamination assessment of} top soils in mining industry areas

The contents of heavy metals and the results of ecological risk warning assessment of top soils in mining industry areas are shown in Table 4 . The correlation analysis for total contents of heavy metals and the primary heavy metals in top soils are shown in Table 5.

In the top soils of collection site (no plant), the contents of $\mathrm{Cd}, \mathrm{As}$, and $\mathrm{Hg}$ in soils were higher than the limit values of the environmental quality standard for soil of China (GB 15618-1995). The frequently observed contents of heavy metals in soils scheme was as follows: Mo> $\mathrm{Pb}>\mathrm{Zn}>\mathrm{Cr}>\mathrm{As}>\mathrm{Cu}>\mathrm{Cd}>\mathrm{Ni}>\mathrm{Hg}$. The ecological risk index of the top soil was 85.17 , and the degree of warning was serious. The results meant the soil was contaminated seriously by heavy metals. The correlation coefficient between $\mathrm{Cd}$ and As was $0.93(P<0.01)$. The high positive correlation coefficient indicates the two metals relate closely and may be from the same pollution source. In other words, the results meant that the source of $\mathrm{Cd}$ and As may be identical [31,32]. The correlation coefficient between $\mathrm{Mo}$ and $\mathrm{Hg}$ was $0.68(P<0.01)$, because $\mathrm{Hg}$ may be the accompaniment element for Mo. The correlation coefficients between $\mathrm{Pb}$ and other heavy metals were preferable for higher background of $\mathrm{Pb}$ in soils and the existing of outside source of contamination. The contents of heavy metals in top soils of collection site were higher than those in top soils of transportation and tailing site, it may be due to the reasons: no phytoremediation, dust fall, residue in the open air, higher background in soil-forming process (Mo \& As), accompaniment element $(\mathrm{Hg})$, automobile exhaust $(\mathrm{Pb} \& \mathrm{Ni})$, the wear of the tire and brake $(\mathrm{Zn}, \mathrm{Cd}, \mathrm{Cr}$, and $\mathrm{Cu})[33]$.

In the top soils of transportation site, the heavy metal distribution and the pollution status is similar. The correlation coefficient between $\mathrm{Cd}$ and As was $0.97 \quad(P<0.01)$. The appreciable correlation exists between $\mathrm{Pb}$ or $\mathrm{Zn}$ and $\mathrm{As} \& \mathrm{Cd}(P<0.01)$. The heavy metals source in the top soils of transportation site may be from as follows: higher background in soil-forming process (Mo \& As) [34], automobile exhaust $(\mathrm{Pb} \& \mathrm{Ni})$, the wear of tires and brakes $(\mathrm{Zn}, \mathrm{Cd}, \mathrm{Cr}$, and $\mathrm{Cu})$, and the leave out of ore [35]. The ecological risk index of the topsoil was 72.90 , and the degree of warning was serious. The results meant that the soil of transportation site was contaminated seriously by heavy metals. Compared with the collection site (index was 85.17), the ecological risk index of top soils in transportation site was lower. It may be due to the phytoextraction of heavy metals by plants in transportation site [36].

In the top soils of tailing site, the contents of $\mathrm{Cd} \& \mathrm{As}$ in soils were higher than the environmental quality standard for contaminated soil of China (GB 15618-1995). The frequently observed contents of heavy metals in soils scheme was as follows: $\mathrm{Mo}>\mathrm{Pb}>\mathrm{Zn}>\mathrm{Cr}>\mathrm{Cu}>\mathrm{As}>$ $\mathrm{Cd}>\mathrm{Ni}>\mathrm{Hg}$. Only the content of $\mathrm{Cu}$ was higher than As in the top

\begin{tabular}{|c|c|c|c|c|c|c|c|c|c|c|}
\hline Site & Heavy metals & As & $\mathrm{Cd}$ & $\mathrm{Cr}$ & $\mathrm{Cu}$ & $\mathrm{Hg}$ & $\mathrm{Mo}^{*}$ & $\mathrm{Ni}$ & $\mathrm{Pb}$ & Zn \\
\hline \multirow{5}{*}{ Collection site } & $\begin{array}{l}\text { Contents } \\
\left(\mathrm{mg} \mathrm{kg}^{-1}\right)\end{array}$ & $\begin{array}{l}167.65 \pm \\
41.58\end{array}$ & $\begin{array}{l}83.09 \pm \\
16.62\end{array}$ & $\begin{array}{l}201.98 \pm \\
75.12\end{array}$ & $\begin{array}{l}131.68 \pm \\
26.05\end{array}$ & $\begin{array}{l}4.78 \pm \\
2.09\end{array}$ & $\begin{array}{l}1142.89 \pm \\
793.29\end{array}$ & $\begin{array}{l}67.52 \pm \\
50.82\end{array}$ & $\begin{array}{l}398.29 \pm \\
131.00\end{array}$ & $\begin{array}{l}278.94 \pm \\
79.57\end{array}$ \\
\hline & CAi / CRi & 4.19 & 83.09 & 0.67 & 0.33 & 3.19 & - & 0.34 & 0.80 & 0.56 \\
\hline & $\mathrm{pH}$ & \multicolumn{9}{|l|}{7.08} \\
\hline & IER & \multicolumn{9}{|l|}{85.17} \\
\hline & Degree of warning & \multicolumn{9}{|c|}{ serious warning } \\
\hline \multirow{5}{*}{ Transportation site } & $\begin{array}{l}\text { Contents } \\
\left(\mathrm{mg} \mathrm{kg}^{-1}\right)\end{array}$ & $\begin{array}{l}153.90 \pm \\
42.53\end{array}$ & $\begin{array}{l}73.04 \pm \\
18.96\end{array}$ & $\begin{array}{l}166.43 \pm \\
74.15\end{array}$ & $\begin{array}{l}122.16 \pm \\
30.98\end{array}$ & $\begin{array}{l}2.62 \pm \\
1.70\end{array}$ & $\begin{array}{l}912.00 \pm \\
865.52\end{array}$ & $\begin{array}{l}42.49 \pm \\
32.59\end{array}$ & $\begin{array}{l}334.22 \pm \\
138.80\end{array}$ & $\begin{array}{l}253.55 \pm \\
84.11\end{array}$ \\
\hline & $\mathrm{CAi} / \mathrm{CRi}$ & 3.85 & 73.04 & 0.56 & 0.31 & 1.75 & - & 0.21 & 0.67 & 0.51 \\
\hline & $\mathrm{pH}$ & \multicolumn{9}{|l|}{7.28} \\
\hline & IER & \multicolumn{9}{|l|}{72.90} \\
\hline & Degree of warning & \multicolumn{9}{|c|}{ serious warning } \\
\hline \multirow{5}{*}{ Tailing site } & $\begin{array}{l}\text { Contents } \\
\left(\mathrm{mg} \mathrm{kg}^{-1}\right)\end{array}$ & $\begin{array}{l}121.98 \pm \\
29.05\end{array}$ & $\begin{array}{l}59.46 \pm \\
12.46\end{array}$ & \begin{tabular}{|l|}
$154.85 \pm$ \\
72.78
\end{tabular} & \begin{tabular}{|l|}
$129.92 \pm$ \\
28.97
\end{tabular} & $\begin{array}{l}2.86 \pm \\
0.61\end{array}$ & $\begin{array}{l}720.61 \pm \\
312.54\end{array}$ & \begin{tabular}{|l}
$42.42 \pm$ \\
20.11
\end{tabular} & $\begin{array}{l}298.67 \pm \\
235.00\end{array}$ & \begin{tabular}{|l}
$205.85 \pm$ \\
69.36
\end{tabular} \\
\hline & $\mathrm{CAi} / \mathrm{CRi}$ & 3.05 & 59.46 & 0.52 & 0.33 & 0.40 & - & 0.21 & 0.60 & 0.41 \\
\hline & $\mathrm{pH}$ & \multicolumn{9}{|l|}{6.09} \\
\hline & IER & \multicolumn{9}{|l|}{56.98} \\
\hline & Degree of warning & \multicolumn{9}{|c|}{ serious warning } \\
\hline
\end{tabular}

No assessment for Mo. 20 samplings were selected and determined in each site. Shown values are the means and standard errors of 3 replicate $(P<0.05)$.

Table 4: Contents of heavy metals and the results of ecological risk warning assessment for top soils in mining industry areas.

\begin{tabular}{|c|c|c|c|c|c|c|c|c|c|c|}
\hline Site & Heavy metals & As & $\mathrm{Cd}$ & $\mathrm{Cr}$ & $\mathrm{Cu}$ & $\mathrm{Hg}$ & Mo & $\mathrm{Ni}$ & $\mathrm{Pb}$ & $\mathrm{Zn}$ \\
\hline \multirow{3}{*}{ Collection site } & As & - & $0.93 a$ & 0.48 & 0.06 & $-0.51 c$ & 0.19 & 0.35 & $0.90 a$ & $0.77 b$ \\
\hline & $\mathrm{Cd}$ & & - & $0.52 c$ & 0.12 & -0.21 & 0.17 & 0.26 & $0.78 b$ & $0.85 a$ \\
\hline & $\mathrm{Hg}$ & & & $0.51 \mathrm{c}$ & 0.25 & - & $0.68 c$ & -0.05 & -0.29 & 0.25 \\
\hline \multirow{3}{*}{ Transportation site } & As & - & $0.97 a$ & 0.40 & -0.14 & $-0.63 c$ & 0.04 & 0.07 & $0.94 a$ & $0.85 a$ \\
\hline & $\mathrm{Cd}$ & & - & 0.49 & -0.10 & -0.37 & 0.10 & 0.25 & $0.91 \mathrm{a}$ & $0.84 a$ \\
\hline & $\mathrm{Hg}$ & & & 0.18 & -0.02 & - & 0.20 & 0.06 & -0.48 & -0.10 \\
\hline \multirow{2}{*}{ Tailing site } & As & - & $0.99 a$ & $0.54 \mathrm{c}$ & -0.11 & $-0.67 c$ & 0.17 & 0.33 & 0.32 & $0.72 b$ \\
\hline & $\mathrm{Cd}$ & & - & $0.53 c$ & 0.10 & $-0.67 c$ & 0.19 & 0.34 & 0.25 & $0.71 \mathrm{~b}$ \\
\hline
\end{tabular}

Significant at $P<0.01$. Different letters indicate statically significant differences between heavy metals (ANOVA and Fisher LSD test)

Table 5: Correlation analysis between total contents of heavy metals and contents of primary heavy metals in mining industry top soils. 
soils compared with collection and transportation sites, it may be due to the lower $\mathrm{pH}$ and As existing as anion [37]. The mobility of $\mathrm{Cu}$ was powerful than As under low $\mathrm{pH}$ in soil of the tailing ore [38]. The $\mathrm{pH}$ of soil in this site was lowest, because sulfide minerals were oxidated and formed acids in soils. The ecological risk index of the topsoil was 56.98 which the degree of warning was serious. The results meant the soil was contaminated seriously by heavy metals. The correlation coefficient between $\mathrm{Cd}$ and As was $0.93(P<0.01)$. The appreciable correlation exists between $\mathrm{Zn}$ and $\mathrm{As} \& \mathrm{Cd}(P<0.01)$. The heavy metals source in the top soils of tailing site may be from as follows: higher background in soil-forming process (Mo \& As) and releasing of heavy metals in the tailing ore.

\section{Heavy metal distribution, chemical fractions, and contami- nation assessment of top soils in agricultural area}

The contents of heavy metals and the results of ecological risk warning assessment for top soils in mining industry areas are shown in Table 6. The correlation analysis for total contents of heavy metals and the primary heavy metals in mining industry top soils are shown in Table 7. The chemical fractions of heavy metals in top soils of agricultural area are shown in Figures 1-3. In the top soils of agricultural site, the heavy metal distribution is different. The frequently observed contents of chemical fractions for heavy metals in soils scheme were as follows commonly: residual $>$ oxidable $>$ reducible $>$ acid soluble

In the top soils of agricultural area near the collection site, the main contaminations were $\mathrm{Cd}, \mathrm{Cr}, \mathrm{Hg}, \mathrm{Ni}, \mathrm{Zn}$, and $\mathrm{Cu}$. It meant the soils were contaminated by combined contamination. The ecological risk index of the topsoil was 38.52 which the degree of warning was serious. The correlation coefficient of heavy metals between soil and underground water was $-0.23(n=9)$, it was shown that the heavy metals in soils were not absolutely from the underground water for irrigation [39]. The contents chemical fractions of Mo were oxidable $>$ residual, it may be related to the action of collection [40].

In the top soils of agricultural area near the transportation site, the main contaminations were $\mathrm{Cd}, \mathrm{Cr}$, and $\mathrm{Hg}$. The ecological risk index of the top soil was 9.00 which the degree of warning was serious. The correlation coefficient of heavy metals between soil and underground water was $0.37(n=9)$, it was shown that the heavy metals in soils were not absolutely from the underground water for irrigation [39]. No appreciable correlation exists between $\mathrm{Hg}$ and other heavy metals $(P<0.01)$, it meant the source of $\mathrm{Hg}$ in soils is different to other heavy metals. The contents of $\mathrm{Hg}$ in soils were higher in the top soils of agricultural area than those in mining industry areas, due to the use

\begin{tabular}{|c|c|c|c|c|c|c|c|c|c|c|}
\hline Site & Heavy metals & As & $\mathrm{Cd}$ & $\mathrm{Cr}$ & $\mathrm{Cu}$ & $\mathrm{Hg}$ & $\mathrm{Mo}^{*}$ & $\mathrm{Ni}$ & $\mathrm{Pb}$ & $\mathrm{Zn}$ \\
\hline \multirow{5}{*}{ Collection site } & $\begin{array}{l}\text { Contents } \\
\left(\mathrm{mg} \mathrm{kg}^{-1}\right)\end{array}$ & $\begin{array}{c}33.11 \pm \\
9.01\end{array}$ & $\begin{array}{c}10.45 \pm \\
3.17\end{array}$ & $\begin{array}{c}3353.60 \pm \\
1900.34\end{array}$ & $\begin{array}{c}968.82 \pm \\
311.08\end{array}$ & $\begin{array}{c}12.19 \pm \\
2.16\end{array}$ & $\begin{array}{c}228.38 \pm \\
89.08\end{array}$ & $\begin{array}{c}1556.80 \pm \\
321.79\end{array}$ & $\begin{array}{c}459.94 \pm \\
91.26\end{array}$ & $\begin{array}{c}2407.10 \pm \\
555.36\end{array}$ \\
\hline & CAi / CRi & 0.828 & 10.45 & 11.18 & 2.42 & 8.13 & - & 7.78 & 0.92 & 4.81 \\
\hline & $\mathrm{pH}$ & \multicolumn{9}{|c|}{8.46} \\
\hline & IER & \multicolumn{9}{|c|}{38.52} \\
\hline & Degree of warning & \multicolumn{9}{|c|}{ serious warning } \\
\hline \multirow{5}{*}{ Transportation site } & $\begin{array}{l}\text { Contents } \\
\left(\mathrm{mg} \mathrm{kg}^{-1}\right)\end{array}$ & $\begin{array}{c}6.14 \pm \\
1.05\end{array}$ & $\begin{array}{c}4.20 \pm \\
1.92\end{array}$ & $\begin{array}{c}329.37 \pm \\
59.94\end{array}$ & $\begin{array}{c}379.28 \pm \\
98.58\end{array}$ & $\begin{array}{c}14.11 \pm \\
2.01\end{array}$ & $\begin{array}{c}304.91 \pm \\
120.44\end{array}$ & $\begin{array}{c}121.85 \pm \\
29.66\end{array}$ & $\begin{array}{c}78.89 \pm \\
19.53\end{array}$ & $\begin{array}{c}217.10 \pm \\
77.00\end{array}$ \\
\hline & CAi / CRi & 0.15 & 4.20 & 1.10 & 0.95 & 9.40 & - & 0.61 & 0.16 & 0.43 \\
\hline & $\mathrm{pH}$ & \multicolumn{9}{|c|}{6.81} \\
\hline & IER & \multicolumn{9}{|c|}{9.00} \\
\hline & Degree of warning & \multicolumn{9}{|c|}{ serious warning } \\
\hline \multirow{5}{*}{ Tailing site } & $\begin{array}{l}\text { Contents } \\
\left(\mathrm{mg} \mathrm{kg}^{-1}\right)\end{array}$ & $\begin{array}{c}5.45 \pm \\
2.92\end{array}$ & $\begin{array}{c}4.49 \pm \\
1.58\end{array}$ & $\begin{array}{c}528.14 \pm \\
100.06\end{array}$ & $\begin{array}{c}198.21 \pm \\
40.57\end{array}$ & $\begin{array}{c}7.77 \pm \\
2.89\end{array}$ & $\begin{array}{c}704.14 \pm \\
250.05\end{array}$ & $\begin{array}{c}227.87 \pm \\
57.88\end{array}$ & $\begin{array}{c}81.60 \pm \\
29.10\end{array}$ & $\begin{array}{c}481.80 \pm \\
106.76\end{array}$ \\
\hline & $\mathrm{CAi} / \mathrm{CRi}$ & 0.14 & 4.49 & 1.76 & 0.50 & 5.18 & - & 1.14 & 0.16 & 0.84 \\
\hline & $\mathrm{pH}$ & \multicolumn{9}{|c|}{5.47} \\
\hline & IER & \multicolumn{9}{|c|}{6.21} \\
\hline & Degree of warning & \multicolumn{9}{|c|}{ serious warning } \\
\hline
\end{tabular}

No assessment for Mo. 20 samplings were selected and determined in each site. Shown values are the means and standard errors of 3 replicate $(P<0.05)$.

Table 6: Contents of heavy metals and the results of ecological risk warning assessment for top soils in agricultural areas.

\begin{tabular}{|c|c|c|c|c|c|c|c|c|c|c|}
\hline Site & Heavy metals & As & $\mathrm{Cd}$ & $\mathrm{Cr}$ & $\mathrm{Cu}$ & $\mathrm{Hg}$ & Mo & $\mathrm{Ni}$ & $\mathrm{Pb}$ & $\mathrm{Zn}$ \\
\hline \multirow{6}{*}{ Collection site } & $\mathrm{Cd}$ & $0.79 b$ & - & & & & $0.86 a$ & & $0.88 a$ & \\
\hline & $\mathrm{Cr}$ & 0.48 & $0.87 a$ & - & & & $0.85 a$ & & $0.99 a$ & \\
\hline & $\mathrm{Hg}$ & 0.30 & $0.81 b$ & $0.95 a$ & $0.94 a$ & - & $0.66 \mathrm{~d}$ & & 0.91a & \\
\hline & $\mathrm{Cu}$ & 0.43 & $0.87 a$ & $1.0 a$ & - & & $0.75 b$ & & $0.98 a$ & \\
\hline & $\mathrm{Ni}$ & 0.42 & $0.87 a$ & $1.0 \mathrm{a}$ & $1.0 \mathrm{a}$ & $0.94 a$ & $0.75 b$ & - & $0.98 a$ & \\
\hline & $\mathrm{Zn}$ & 0.43 & $0.87 a$ & $1.0 \mathrm{a}$ & $1.0 \mathrm{a}$ & $0.94 a$ & $0.76 b$ & $1.0 \mathrm{a}$ & $0.97 a$ & - \\
\hline \multirow{3}{*}{ Transportation site } & $\mathrm{Cd}$ & $0.81 \mathrm{~b}$ & - & & 0.09 & & 0.20 & 0.09 & $0.62 d$ & 0.25 \\
\hline & $\mathrm{Cr}$ & -0.10 & 0.06 & - & $0.94 a$ & & -0.15 & 1.0 & 0.35 & $0.96 a$ \\
\hline & $\mathrm{Hg}$ & -0.13 & -0.17 & -0.26 & -0.18 & - & -0.05 & -0.26 & -0.15 & -0.27 \\
\hline \multirow{4}{*}{ Tailing site } & $\mathrm{Cd}$ & $0.89 a$ & - & & $0.93 a$ & & -0.02 & & $0.75 b$ & $0.87 a$ \\
\hline & $\mathrm{Cr}$ & $0.88 a$ & $0.91 a$ & - & $0.99 a$ & & 0.12 & & $0.86 a$ & $0.97 a$ \\
\hline & $\mathrm{Hg}$ & 0.30 & 0.40 & 0.50 & 0.46 & - & 0.11 & & 0.55 & 0.42 \\
\hline & $\mathrm{Ni}$ & $0.88 a$ & $0.92 a$ & $1.0 a$ & $1.0 \mathrm{a}$ & 0.47 & 0.11 & - & $0.86 a$ & $0.97 a$ \\
\hline
\end{tabular}

Significant at $P<0.01$. Different letters indicate statically significant differences between heavy metals (ANOVA and Fisher LSD test)

Table 7: Correlation analysis between total contents of heavy metals and contents of primary heavy metals in agricultural top soils. 


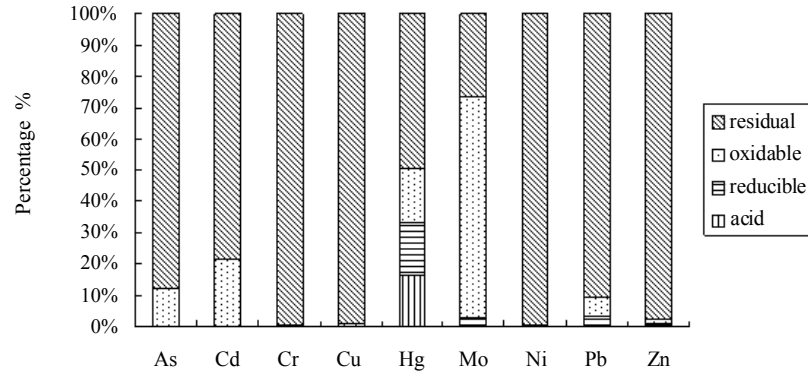

Figure 1: Heavy metals chemical fractions of top soils in agricultural area of collection site.

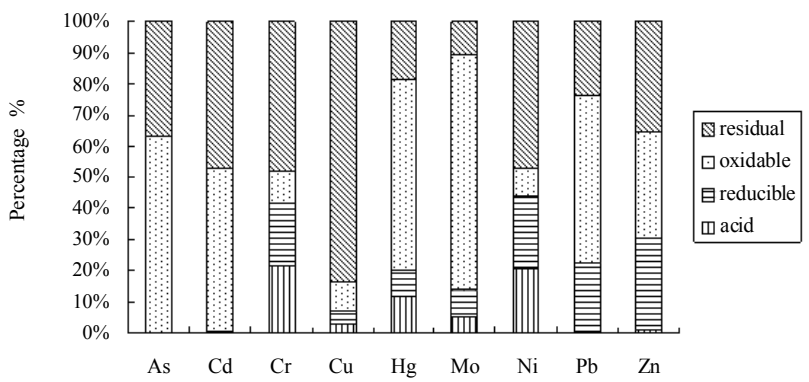

Figure 2: Heavy metals chemical fractions of top soils in agricultural area of transportation site.

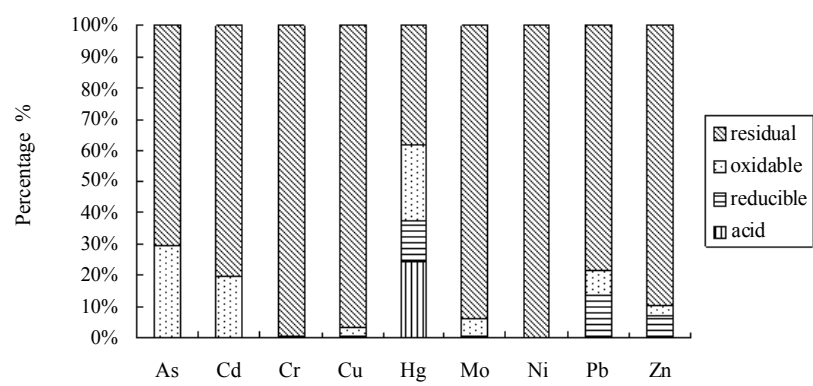

Figure 3: Heavy metals chemical fractions of top soils in agricultural area of tailing site.

of pesticide including mercury. The results indicated that the amount of $\mathrm{Cr}, \mathrm{Hg}, \mathrm{Mo}, \mathrm{Ni}$, and $\mathrm{Cu}$ would be released into the environment if conditions became more acidic. It is the fraction with the most dangerous for the environment [41].

In the top soils of agricultural area near the tailing site, the main contaminations were $\mathrm{Cd}, \mathrm{Cr}, \mathrm{Hg}$, and $\mathrm{Ni}$. The ecological risk index of the topsoil was 6.21 which the degree of warning was serious. The correlation coefficient of heavy metals between soil and underground water was $0.67(n=9)$, it was shown that the heavy metals in soils were relevant to the underground water for irrigation [42]. The appreciable correlation exists between $\mathrm{Cd}$ and $\mathrm{Cr}, \mathrm{Cu}, \mathrm{Ni}$, and $\mathrm{Zn}(P<0.01)$, it meant the source of heavy metals in soils is accordant for the aeolation and leaching process of tailings into soils [43]. The contents chemical fractions of $\mathrm{Pb}$ and $\mathrm{Zn}$ were reducible $>$ oxidable, it may be related to the oxidization of $\mathrm{Pb}$ and $\mathrm{Zn}[44]$

\section{Conclusion}

The soils were collected from mining industry areas (the collection, transportation, and tailing site) and agricultural areas (the vegetable fields near the collection, transportation and tailing site) near the Mo mine. The total contents of $\mathrm{Pb}, \mathrm{As}, \mathrm{Hg}, \mathrm{Cr}, \mathrm{Cd}, \mathrm{Zn}, \mathrm{Cu}, \mathrm{Mo}$, and $\mathrm{Ni}$ in soils and underground water were analyzed by the ICP-OES and carried out ecological risk warning assessment. The chemical fractions were performed using the modified three-stage procedure recommended by BCR. It was found that: the ecological risk indexes of the topsoil in the mining industry areas were 85.17 (collection site), 72.90 (transportation site), and 56.98(tailing site), and which in the agricultural areas were 38.52 (collection site), 9.00 (transportation site), and 6.21 (tailing site). The degrees of warnings were serious warning and meant all soils were contaminated seriously by heavy metals. The sources of heavy metals in top soils around the Mo mine were as follows: dust fall, residue in the open air, higher background in soil-forming process, accompaniment element, automobile exhaust, wear of tires and brakes, release of heavy metals from ore tailing, the application of pesticides and irrigation with wastewater. The frequently observed contents of chemical fractions for heavy metals in soils scheme were as follows commonly: residual > oxidable $>$ reducible $>$ acid soluble.

\section{References}

1. Bhattacharya A, Routh J, Jacks G, Bhattacharya P, Mörth M (2006) Environmental assessment of abandoned mine tailings in Adak, Västerbotten district (northern Sweden). Appl Geochem 21: 1760-1780.

2. Zhou QX, Ren LP, Sun TH, Song YF, Wang X (2002) Contaminative and Interfacial Processes of Soil Cadmium in a Lead-zinc Mining Area. Chin J Soil Sci 33: 300-302.

3. Bityukova L, Shogenova A, Birke M (2000) Urban geochemistry: A study of element distributions in the soils of tallin (Estonia). Environ Geochem Health 22: 173-193.

4. Merian E (1991) Metals and their compounds in the environment: occurrence analysis and biological relevance. VCH, Weinheim 1373.

5. European Commission (2006) Impact Assessment of the Thematic Strategy on Soil Protection. Document accompanying the Thematic Strategy for Soil Protection, Communication from the commission to the council, the European Parliament, the Economic and Social Committee and the Committee of the Regions. European Commission, Brussels.

6. Yu RL, Yuan X, Zhao YH, Hu G, Tu X (2008) Heavy metal pollution in intertidal sediments from Quanzhou Bay. China. J Environ Sci 20: 664-669.

7. Eduljee GH (2000) Trends in risk assessment and risk management. Sci Total Environ 249: 13-23.

8. Suter GW (2006) Ecological Risk Assessment and Ecological Epidemiology fo Contaminated Sites. Hum Ecol Risk Assess 12: 31-38.

9. Kookana R, Correll R, Barnes M (2006) Ecological Risk Assessment fo Terrestrial Ecosystems: The Summary of Discussions and Recommendations from the Adelaide Workshop. Hum Ecol Risk Assess 12: 130-138.

10. Prasad B, Bose J (2001) Evaluation of the heavy metal pollution index for surface and spring water near a limestone mining area of the lower Himalayas. Environ Geol 41: 183-188.

11. Teixeira EC, Ortiz LS, Alves MF, Sanchez J (2001) Distribution of selected heavy metals influvial sedi-ments of the coal mining region of Baixo Jacui, RS Brazil. Environ Geol 41: 145-154.

12. Adriano DC (1986) Trace Elements in the Terrestrial Environments. New York Springer-Verlag Inc 329.

13. Lovely DR (1995) Microbial Reduction of Iron, Manganese, and Other Metals Adv Agron 54: 175-231.

14. Warington K (1995) The influence of high concentrations of ammonium and sodium molybdates on flax, soybean and peas grown in nutrient solutions containing deficient or excess iron. Ann Applied Biol 43: 709-719.

15. Agarwala SC, Hewitt E J (1954) Molybdenum as a Plant Nutrient V. The interrelationships of molybdenum and nitrate supply in the concentration of sugars, nitrate and organic nitrogen in cauliflower plants grown in sand culture. J Hort Sci 29: 291-300

16. Sylvie B, Patrick AN (2010) The potential roles of lime and molybdenum on the 
Citation: Qu J, Yuan X, Wang X, Shao P, Cong Q (2012) Distribution of Heavy Metals, Chemical Fractions and Ecological Risks around a Molybdenum Mine in Liaoning Province, China. Vitam Trace Elem 1:104.

growth, nitrogen fixation and assimilation of metabolites in nodulated legume: A special reference to Phaseolus vulgaris L. Afr J Biotechnol 17: 2482-2489.

17. Togay $Y$, Togay N, Dogan $Y$ (2008). Research on the effect of phosphorus and molybdenum applications on the yield and yield parameters in lentil (Lens culinaris Medic.) Afr J Biotechnol 7: 1256-1260.

18. Stefánsson A, Gunnarsson I, Giroud N (2007). New methods for the direct determination of dissolved inorganic, organic and total carbon in natural waters by Reagent-Free Ion Chromatography and inductively coupled plasma atomic emission spectrometry. Anal Chim Acta 582: 69-74.

19. Mermet JM (2005) Is it still possible, necessary and beneficial to perform research in ICP-atomic emission spectrometry? J Anal At Spectrom 20: 11-16.

20. Tessier A, Campbell PGC, Bisson M (1979) Sequential extraction procedure for the speciation of particulate trace metals. Anal Chem $51: 844-851$

21. Ure AM, Quevauviller P, Muntau H, Griepink B (1993) Speciation of heavy-metals in soils and sediments: an account of the improvement and harmonization of extraction techniques undertaken under the auspices of the $\mathrm{BCR}$ of the Cornmission-of-the-European-Communities. Int J Environ Anal Chem 51: 135-151.

22. Gleyzes C, Tellier S, Astruc M (2002) Fractionation studies of trace elements in contaminated soils and sediments: a review of sequential extraction procedures. Trends Analyst Chem 21: 451-467.

23. Ure AM, Quevauviller PH, Muntau H, Griepink B (1993) Speciation of Heavy Metals in Soils and Sediments, An Account of the Improvement and Harmonization of Extraction Techniques Undertaken Under the Auspices of the $\mathrm{BCR}$ of the Commission of European Communities. Int $\mathrm{J}$ Environ Anal Chem 51: 135-151.

24. Sahuquillo A, López-Sánchez JF, Rubio R, Rauret G, Thomas RP, et al. (1999) Use of a certified reference material for extractable trace metals to assess sources of uncertainty in the BCR three stage sequential extraction procedure. Anal Chim Acta 382: 317-327.

25. Rauret G, López-Sánchez JF, Sahuquillo A, Barahona E, Lachica M, et al (2000) Application of a modified BCR sequential extraction (three-step) procedure for the determination of extractable trace metal contents in a sewage sludge amended soil reference material (CRM 483), complemented by a three-year stability study of acetic acid and EDTA extractable metal content. J Environ Monito 2: 228-233.

26. Rauret G, López-Sánchez JF, Sahuquillo A, Rubio R, Davidson C, et al. (1999) Improvement of the $\mathrm{BCR}$ three step sequential extraction procedure prior to the certification of new sediment and soil reference materials. J Environ Monito 1: $57-61$.

27. Žemberyová M, Barteková J, Hagarová I (2006) The utilization of modified BCR three-step sequential extraction procedure for the fractionation of $\mathrm{Cd}, \mathrm{Cr}, \mathrm{Cu}$, $\mathrm{Ni}, \mathrm{Pb}$ and $\mathrm{Zn}$ in soil reference materials of different origins. Talanta 70: 973978.

28. Qu J, Yuan X, Cong Q, Wang S (2008) Determination of total mass and morphology analysis of heavy metal in soil with potassium biphthalate-sodium hydroxide by ICP-AES. Spectrosc Spect Anal 28: 2674-2678.
29. Qu J, Yuan X, Wang XH, Shao P (2011) Zinc accumulation and synthesis of ZnO nanoparticles using Physalis alkekengi L. Environ Pollut 159: 1783-1788.

30. Rapant S, Kordik J (2003) An environmental risk assessment map of the Slovak Republic: application of data from geochemical atlases. Environ Geol 44: 400-407.

31. Chu N, Zhao YY, Zhang GD (2007) Environmental trait of speciation of heavy metals in low-grade ore plot and soil of the Dawu river domain in the Dexing copper mine, Jiangxi province. Acta Geol Sinica 81: 670-683.

32. 32. Sun C, Bi CJ, Chen ZL, Wang DQ, Zhang C, et al. (2010) Assessment on environmental quality of heavy metals in agricultural soils of Chongming Island, Shanghai City. J Geogr Sci 20: 135-147.

33. Benvenuti M, Mascaro I, Corsini F, Lattanzi P, Parrini P, et al (1997) Mine waste dumps and heavy metal pollution in abandoned mining district of Boccheggiano (Southern Tuscany, Italy). Environ Geol 30: 238-243.

34. Stromberg BO, Banwart S (1994) Kinetic modeling of geochemical processes at the Aitik mining waste rock site in northern Sweden. Appl Geochem 9: 583 595

35. Castrol LJ, Kramar U, Pucheh H (1997) 200 years of mining activities at La Paz/San Luis Potosi/Moxico-consequences for environment and geochemical exploration. J Geochem Explor 58: 81-91.

36. Salt DE, Prince RC, Pickering IJ, Raskin I (1995) Mechanisms of cadmium mobility and accumulation in Indian mustard. Plant Physiol 109: 1427-1433.

37. Ma LQ, Komar KM, Tu C, Zhang W, Cai Y, et al. (2001) A fern that hyperaccumulates arsenic - A hardy, versatile, fast-growing plant helps to remove arsenic from contaminated soils. Nature 409: 579.

38. Rigol A, Mateu J, González NR, Rauret G, Vidal M (2009) pH(stat) vs single extraction tests to evaluate heavy metals and arsenic leachability in environmental samples. Anal Chim Acta 632: 69-79.

39. Egiarte G, Pinto M, Ruíz RE, Camps AM (2008) Monitoring heavy meta concentrations in leachates from a forest soil subjected to repeated applications of biosolid. Environ Pollut 156: 840-848.

40. Kwong YTJ, Roots CF, Roach P, Kettley W (1997) Post-mine metal transport and attenuation in the Keno Hill Mining district, central Yukon, Canada. Environ Geol 30: 98-107.

41. Usero J, Gamero M, Morillo J, Garcia I (1998) Comparative study of three sequential extraction procedures for metals in marine sediments. Environ Int 24: 487-496.

42. Mittal M (2008) Heavy metal accumulation in vegetables irrigated with water from different sources. Food Chem 111: 811-815.

43. Merington G, Alloway BJ (1994) The transfer and fate of Cd, Cu, Pb and $\mathrm{Zn}$ from two historic metallifercus mine in the UK. Appl Geochem 9: 677-687.

44. Lin Z (1997) Mineralogical and chemical characterization of wastes from sulfuric acid industry in Falun, Sweden. Environ Geol 30: 152-162. 